\title{
DIFFICULTIES ENCOUNTERED BY THE BUGINESE LEARNERS IN PRODUCING ENGLISH SOUNDS
}

\author{
Sitti Nurpahmi \\ Fakultas Tarbiyah dan Keguruan UIN Alauddin Makassar \\ Kampus II: Jalan Sultan Alauddin Nomor 36 Samata-Gowa \\ Email: s_pahmi@yahoo.com
}

\begin{abstract}
:
This paper discusses about difficulties encountered by Bugis learner in producing English phonemes. The learners who learn second language use their mother tongue to analyze the second language. They analyze the second language to find the differences and similarities both languages. The similarities can create ease to transfer the language, on the contrary the differences can creates difficulties. Based on the description above it informs that Bugis learners have difficulties in producing the following phonemes: The Labial consonant /f/ and /v/, The interdental consonant $/ \theta /$ and /d/, The alveolar consonant /z/, The consonant palatals / $\hat{s} /$ and /ž/, The vowel /æ/, The diphtong / iə, uə, əu, eə/, English also permits much longer sequences of consonant initially, medially, and finally in utterances. Both English and Buginese have consonant which are conveniently symbolized / $t, d, s, z /$. In English, however, these represent alveolar, whereas in Buginese they represent dentals. All of these differences constitute a major source of difficulty for the Bugis speakersin leaning English.
\end{abstract}

Abstrak:

Tulisan ini membahas tentang kesulitan yang dihadapi oleh pebelajar yang bahasa ibunya adalah bahasa Bugis dalam mengucapkan fonem. Pebelajar yang belajar bahasa kedua menggunakan bahasa ibu mereka untuk menganalisa bahasa kedua. Mereka menganalisa bahasa kedua untuk menemukan perbedaan dan persamaan diantara kedua bahasa. Persamaan akan memudahkan untuk mentansfer bahasa kedua, dan sebaliknya perbedaan dapat menyulitkan. Pebelajar yang bahasa ibunya adalah bahasa Bugis mempunyai kesulitan dalam menybutkan fnem-fonem berikut: konsonan bilabial/f/ dan /v/. konsonanm interdental $/ \theta /$ and $/ \mathrm{d} /$, konsonan alveolar $/ \mathrm{z} / /$ the konsonan palatal $/ \hat{\mathrm{s}} /$ and /ž/, vokal /æ/, diftong / iə, uə, əu, eə/. Bahasa Inggris dan bahasa Bugis mempunyai konsonan / $\mathrm{t}, \mathrm{d}, \mathrm{s}, \mathrm{z} /$. Namun demikian dalam bahasa Inggris dikategorikan sebagai alveolar sementara dalam bahasa Bugis dikategorikan sebagai dental. Perbedaan-perbedaan tersebut menyebabkan kesulitan bagi pebelajar bahasa inggris untuk menghasilkan bunyi-bunyi dalam bahasa Inggris.

LANGUAGE is a purely human and non-instinctive method of communicating ideas, emotions, and desires by means of a system of voluntarily produced symbols. These symbols are, in the first instance, auditory and they are produced by the so-called "organs of speech." 1 The organs of speech produced speech sound that can be understood by other people. So the language that is used to communicate is actually a combination of meaningful sound.

Language is a socially shared, rule-governed code used for communication. Speech is the audible, oral output of language. ${ }^{2}$ Furthermore, Language, due to its 
specific properties, is one aspect that makes human beings unique in comparison to other animals and species. The properties include communication, arbitrary symbolism, regular structure, structure at multiple levels, generation and production, and dynamism. ${ }^{3}$ Languages are produced by people in the form of sound through the organ of speech. Language varies across different cultures and with different people. Different languages use distinctive phonemes, which are the smallest units of sound differently.

Saville-Troike explain that contrastive analysis focuses on the differences and similarities between the L1 and the Second Language (L2). This means that the similarities and differences between L1 and L2 play a crucial role in learners' production. ${ }^{4}$ The learner analyzes the second language to find the differences and similarities both languages. The similarities can create ease to transfer the language, on the contrary the differences can creates difficulties.

\section{ENGLISH PHONEMES}

In the following table the classification of consonant based on the place of articulation and the manner of articulation 5 :

\begin{tabular}{|c|c|c|c|c|c|c|c|c|c|c|c|c|c|c|}
\hline $\begin{array}{c}\text { Place of } \\
\text { Articulation }\end{array}$ & \multicolumn{2}{|c|}{ Bilabial } & \multicolumn{2}{|c|}{ Labiodental } & \multicolumn{2}{|c|}{ Interdental } & \multicolumn{2}{c|}{ Alveolar } & \multicolumn{2}{c|}{ Palatal } & \multicolumn{3}{c|}{ Velar } & \multicolumn{2}{c|}{ Glotal } \\
\hline $\begin{array}{c}\text { Manner of } \\
\text { Articulation }\end{array}$ & Voice & $\begin{array}{l}\text { Voice } \\
\text { Less }\end{array}$ & Voice & Voice less & Voice & Voice & Voice & $\begin{array}{l}\text { Voice } \\
\text { Less }\end{array}$ & Voice & $\begin{array}{l}\text { Voice } \\
\text { less }\end{array}$ & Voice & $\begin{array}{l}\text { Voice } \\
\text { less }\end{array}$ & $\begin{array}{l}\text { Voice } \\
\text { Loice } \\
\text { Less }\end{array}$ \\
\hline Stop & $\mathrm{p}$ & $\mathrm{p}$ & & & & & $\mathrm{t}$ & $\mathrm{d}$ & & & $\mathrm{k}$ & $\mathrm{g}$ & & \\
\hline Fricatives & & & $\mathrm{f}$ & $\mathrm{v}$ & $\theta$ & $\delta$ & $\mathrm{s}$ & $\mathrm{z}$ & $\hat{\mathrm{s}}$ & $\mathrm{z}$ & & & $\mathrm{h}$ & \\
\hline Affricatives & & & & & & & & & $\hat{\mathrm{c}}-$ & $\mathrm{j}$ & & & & \\
\hline Nasals & & $\mathrm{m}$ & & & & & & $\mathrm{n}$ & & & & $\mathrm{n}$ & & \\
\hline Lateral & & & & & & & & $\mathrm{l}$ & & & & & & \\
\hline Semivowel & & $\mathrm{w}$ & & & & & & $\mathrm{r}$ & & $\mathrm{y}$ & & & & \\
\hline
\end{tabular}

The following distribution is the two-way classification of English Vowel: ${ }^{6}$

\begin{tabular}{|c|c|c|c|}
\hline \multirow{2}{*}{ Height of Tongue } & \multicolumn{3}{|c|}{ Part of Tongue Involved } \\
\hline & Front & Central & Back \\
\hline \multirow{3}{*}{ High } & i: beet & & $\mathrm{u}$ : boot \\
\hline & I bit & i marry & $\mathrm{u}$ put \\
\hline & e bait & & o boat \\
\hline \multirow[t]{2}{*}{ Mid } & & ə Sofa & \\
\hline & $\varepsilon$ bet & & o: bought \\
\hline Low & $æ$ bat & $\Lambda$ but & a pot \\
\hline
\end{tabular}

\section{BUGINESE PHONEMES}

In the labial it to velar region Bugis language has sixteen consonants and in the 
post velar region, language has seven consonants. The details are given in the following chart: ${ }^{7}$

\begin{tabular}{|c|c|c|c|c|c|c|c|c|c|c|}
\hline Place of & Bilabial & & Dent & & pal & & & & Gl & \\
\hline $\begin{array}{l}\text { Manner of } \\
\text { Articulation }\end{array}$ & 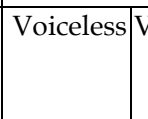 & Voiced & $\begin{array}{l}\text { Voice } \\
\text { less }\end{array}$ & Voiced & $\begin{array}{l}\text { Voice } \\
\text { less }\end{array}$ & Voiced & $\begin{array}{l}\text { Voice } \\
\text { less }\end{array}$ & Voiced & $\begin{array}{c}\text { Voice } \\
\text { less }\end{array}$ & Voiced \\
\hline Stop & $\mathrm{p}$ & $\mathrm{b}$ & $\mathrm{t}$ & d & & & $\mathrm{k}$ & g & ? & \\
\hline Fricatives & & & $S$ & $\mathrm{z}$ & & & $\mathrm{h}$ & & & \\
\hline Affricates & & & & & $c, n, c$ & $\mathrm{j}$ & & & & \\
\hline Nasals & & $\mathrm{m}$ & & $\mathrm{n}$ & & & & $\eta$ & & \\
\hline Lateral & & & & $1, r$ & & & & & & \\
\hline Semivowel & & $\mathrm{w}$ & & & & $\mathrm{y}$ & & & & \\
\hline
\end{tabular}

Classification of consonant based on the place of articulation:

$\begin{array}{lllllll}\text { Bilabial } & \mathrm{p} & \mathrm{b} & \mathrm{m} & \mathrm{w} & & \\ \text { Dental t } & \mathrm{d} & \mathrm{s} & - & \mathrm{n} & \mathrm{l} & \mathrm{r} \\ \text { Palatal c } & \mathrm{j} & - & - & \mathrm{y} & \mathrm{nc} & \\ \text { Velar } & \mathrm{k} & \mathrm{g} & \mathrm{\eta} & \mathrm{h} & & \\ \text { Glottal } & ? & & & & & \end{array}$

Below the classification of consonant based on the manner of articulation:

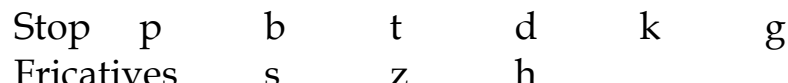

$\begin{array}{llll}\text { Fricatives } & \text { s } & \mathrm{z} & \mathrm{h} \\ \text { Affricatives } & \text { c. } & \mathrm{nc} & \mathrm{j}\end{array}$

Nasal $m \quad n \quad n$

Laterall $\quad r$

Semi vowel w y

Below the classification of consonant based on voice and voiceless of the souds:

$\begin{array}{llllllllll}\text { Voice } & \mathrm{t} & \mathrm{s} & \mathrm{c} & \mathrm{n} & \mathrm{c} & \mathrm{k} & \mathrm{h} & ? & \\ \text { Voiceless } & \mathrm{p} & \mathrm{b} & \mathrm{m} & \mathrm{w} & \mathrm{d} & \mathrm{z} & \mathrm{n} & 1 & \mathrm{r}\end{array}$

\section{Consonant Sequences}

Bugis language has no sequences of more than; two consonants, whether in close transition or with intervening juncture, but it has double consonant, for instance: bb, cc, dd, gg, hh. 


\section{Vowels}

The following table describe the vowel that Buginese phonemes has:

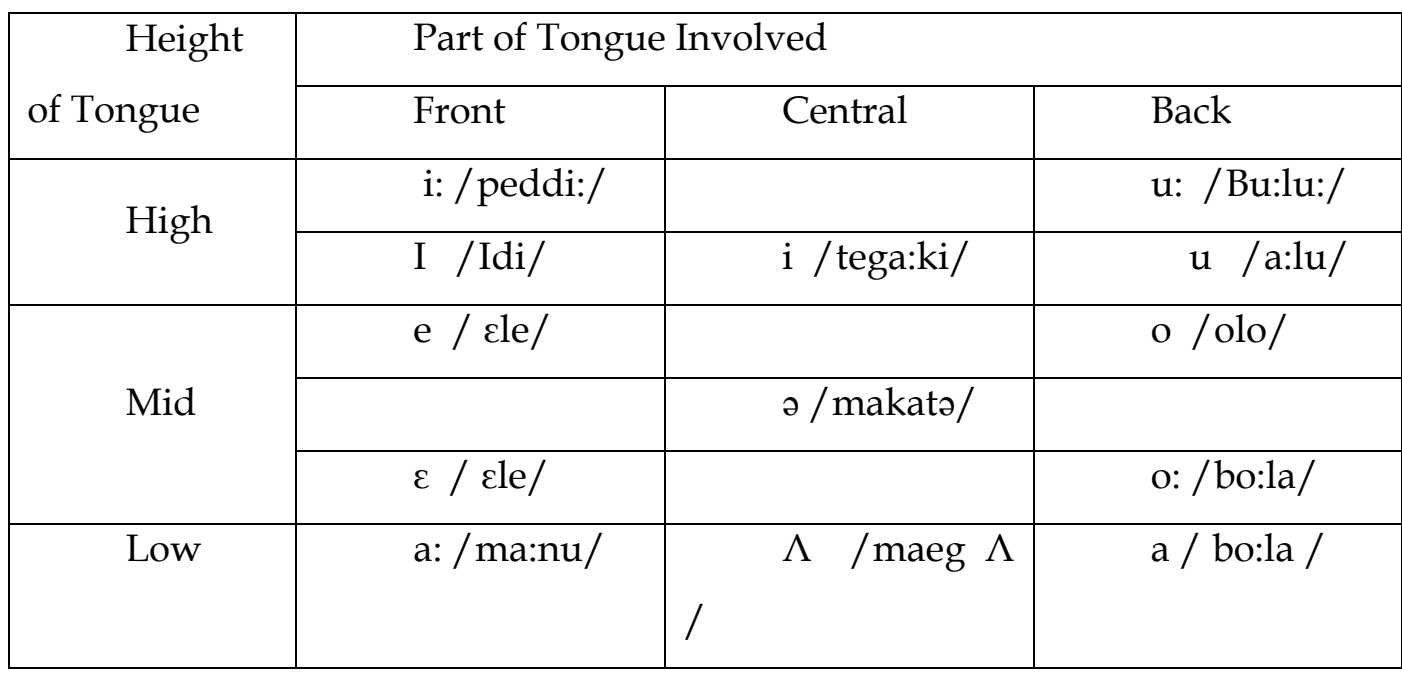

Monofthong

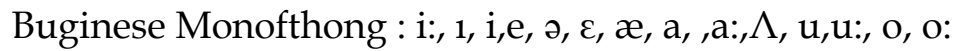

Diphtongs

Buginese Dipthong: ai, ei, au, oe, ui,oi,ue,ai, ua, ia, and iu

\section{THE DIFFERENCES AND SIMILARITIES BETWEEN BUGINESE AND ENGLISH PHONEME}

\section{Consonant}

In the labial to velar region English has twenty three (or twenty -one, depending on how affricatives are analyzed) consonant. But Buginese has only sixteen.. On the other hand, in the post velar regions Buginese has seven consonant, but English only one. The details are given in the following chart:

\begin{tabular}{|c|c|c|c|c|c|c|c|c|}
\hline Language & Bilabial & Labiodental & Interdental & Dentals & Alvelar & Palatals & Velar & Gglotal \\
\hline Buginese & $p, b,-m$ & -- & -- & $\mathrm{t}, \mathrm{d}, \mathrm{s}, \mathrm{z}, \mathrm{n}, \mathrm{l}, \mathrm{r}$ & -, & $c, n c, j,-,, y, y$ & $k, g, \eta, w$ & h,? \\
\hline English & $\mathrm{p}, \mathrm{b}, \mathrm{m}$ & $\mathrm{f} \mathrm{v}$ & $\theta \mathrm{d}$ & -, -,-,-,-,-, & $\mathrm{t}, \mathrm{d}, \mathrm{s}, \mathrm{z}, \mathrm{n}, \mathrm{l}, \mathrm{r}$ & $\hat{\mathrm{c}}_{-}-\mathrm{j}, \hat{\mathrm{s}},(\check{\mathrm{z}}), \mathrm{y}$ & $\mathrm{k}, \mathrm{g}, \mathrm{\eta}, \mathrm{w}$ & $\mathrm{h}$ \\
\hline
\end{tabular}

Bilabial

Buginese $\quad p \quad b \quad m$

English $\quad \mathrm{p} \quad \mathrm{b} \quad \mathrm{m}$

Both English and Buginese have three consonants in labial. Therefore Buginese Learners have no difficulties in producing the phonemes.

Labiodental

Buginese

English

f $\quad$ v


The phoneme like $\mathrm{f}, \mathrm{v}$ do not occur in Buginese, and Buginese speaker substitute $/ \mathrm{p} /$ respectively for $/ \mathrm{f} / / \mathrm{v} /$ or $/ \mathrm{f} /$ for those in some are:

Interdental

Buginese

English

$\theta \quad \delta$

Interdental phonemes like $\theta, \mathrm{d}$ do not occur in Buginese, and Buginese speakers substitute $s$ respectively to $/ \theta /$ and $/ d /$ to $/ \delta /$. The English contrast such as thistlethis' ll, ether - either, think-sink, bath-bass, breathe-brezze are troublesome.

\section{Dentals}

$\begin{array}{lllllllll}\text { Buginese } & \mathrm{t} & \mathrm{d} & \mathrm{s} & - & \mathrm{n} & \mathrm{l} & \mathrm{r} & \\ \text { English } & - & - & - & - & - & - & - & \\ \text { Alveolar } & & & & & & & & \\ \text { Buginese } & - & - & - & - & - & - & - & \\ \text { English } & & \mathrm{t} & \mathrm{d} & \mathrm{s} & \mathrm{z} & \mathrm{n} & 1 & \mathrm{r}\end{array}$

Buginese Phoneme like / $\mathrm{t} / \mathrm{d} / \mathrm{d} /$ are dentals in bugis language and they are alveolar in English. The difference does not constitute a major problem in the learning of English, since substitution of the dentals for the alveolar does not materially affect or impair communication in English. However, consonant / z/ does not exist in Bugis language, so the learners substitute as /s/. The Buginese learners will produce /ziebra/ with /sebra/. Buginese speakers have difficulty with $r$ in all environment and subtitute / $\mathrm{r}$ / which probably least acceptable to speakers of English in items such as bird, shirt, fur, her.

Palatals

$\begin{array}{llllllll}\text { Buginese } & c & j & - & - & y & n c & \\ \text { English } & & \hat{c} & j & \hat{s} & \check{z} & y & -\end{array}$

Bugis learners find many difficulties in producing words consisting / $\hat{\mathrm{s}} /$ and /̌̌/ because the consonant does not exist in Buginese. They substitute those consonant with /s/.

Velar

Buginese $k \quad g \quad n \quad w$

English $\quad \mathrm{k} \quad \mathrm{g} \quad \mathrm{n} \quad \mathrm{w}$

Bugis learners do not find difficulties in producing words consisting of velar consonant because it has similarities with English.

Glotal

Buginese ?

English $\quad h$

English presents no problem in this environment for the speaker of Buginese.

\section{Consonant Sequences}

Buginese language has no sequences of more than two consonant, whether in close transition or with intervening juncture, so the Buginese speaker has obvious difficulty with it and supplies intrusive vowels which act as cluster breakers because the English has as many as four consonant in close transition, and as many as six or seven intervening juncture. The details are as follows: 


\begin{tabular}{llll}
\multirow{3}{*}{ Buginese } & Initial & medial & final \\
& C & C & C \\
\multirow{3}{*}{ English } & CC & CC & CC \\
& C & C & C \\
& CC & CC & CC \\
& CCC & CCC & CCC \\
& CCCC & CCCC &
\end{tabular}

The Buginese learners have difficulties in producing words which contain more than two consonant cluster either ini initial, media, or final. However, they only have very little difficulty. The three consonant sequences in English pronounced with two consonant clusters. World is always pronounced / wo:rd/. /rld/ becomes /ld/. The learners also have only little difficulty in producing more than three consonant sequences., for example: sprite / sprait/. Eventhough the three consonants and the four consonant cluster are not in Bugis language, it does not create big difficulties.

\section{Vowels}

Height of

Tongue

High

Mid

Low

High

Mid

$$
\varepsilon \text { / cle/ }
$$

Low

$\varepsilon$ bet

æ bat
I /Idi/
e / cle/

\section{Part of Tongue Involved}

Central

Back

u: boot

i marry

u put

o boat

ə Sofa

$\Lambda$ but

o: bought

i: /peddi:/

i /trgaki/

ə / makatə/

a: /ma:nu/

$\Lambda / \operatorname{maeg} \Lambda /$

o: /bo:la/

u: /Bu:lu:/

u /wa:ju/

o /o:lo/

\section{Monophthong}

English $\quad:$ i:, I, i,e, ə, $\varepsilon, æ, a, ~, \Lambda, u, u:, o, o:$

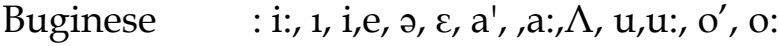

The simple vowel in Bugis language and English similar. The Buginese learners do not have $æ$, so it is difficult to pronounce the words containing those vowel, for example /fæn/ and /væn/ always pronounce / pen/ and/pen/ --or / fen/ and /ven/ in some areas. The buginese learner also do no have short vowel, so the 
learners always produce long vowel for short vowel.

Diphtongs

Buginese Diphtongs: ai, ei, au, oe,ui,oi,ue,ai, ua, ia, and iu

English Diphtongs: ai, ei, oi, iə, uə, əu, au, eə

It seems that the diphthongs in Buginese is more various than those in English. The degree of native like control expected determines the extent to which substitution is a problem. English /ai, ei, oi, au / are not difficult, since they are phonetically similar to Buginese sequences. But English sequences iə, uə, əu, eə seem difficult because those are not in Buginese.

The similarities phoneme between two languages create easiness for the second language learner to pronounce the words. On the contrary the differences between two languages create difficulties for the second learners to pronounce certain words.

\section{THE ERRORS PRODUCED BY THE LEARNERS IN ENGLISH}

The difficulties that the students encountered create some errors in producing words. The following are several errors produced by the Bugis learners:

1. Pronouncing /f/ and /v/.

/pa:Ser/ for the word father

/ perri/ for the word vary

/feori/ for the word vary

2. Pronouncing $/ \theta /$ and / $\delta /$

/ seyk/ for the word thank

/ sink/ for the word think

/sin/ for the word thing

/dis/ for the word this

/der/ for the word there

3. Pronouncing / $\mathrm{z} /$

/sebra/ for the words zebra

/siorəu/ for zero

4. Pronouncing / $\hat{s} /$ and / ž/

/ sou/ for the word show

/ plesər / for the words pleasure

5. Pronouncing /æ/

/pen/ or / fen/ for the word fan.

6. Pronouncing diphthongs

Buginese learners always substitute those diphthong with another. For examples: the word go pronounced by /gou/.

Errors that the Buginese learners produced in some area of phonemes are caused by the phonemes which are not in their first language - Bugis language.

\section{CONCLUSION}

Based on the description above it informs that Buginese learners have difficulties in producing the following phonemes: 
1. The Labial consonant /f/ and / v/.

2. The interdental consonant $/ \theta /$ and $/ \mathrm{d} /$

3. The alveolar consonant $/ \mathrm{z} /$

4. The consonant palatals / $\hat{s} /$ and $/ \check{z} /$

5. The vowel /æ/

6. The diphtong / iə, uə, əu, eə/

English also permits much longer sequences of consonant initially, medially, and finally in utterances. Both English and Buginese have consonant which are conveniently symbolized / $\mathrm{t}, \mathrm{d}, \mathrm{s}, \mathrm{z} /$. In English, however, these represent alveolar, whereas in Buginese they represent dentals. All of these differences constitute a major source of difficulty fort the speaker of Buginese leaning English.

\section{END NOTE}

1. Edward Sapir, An Introduction to the Study of Speech, Project of Guttenburg, 2004, p.4

2. Sarah Morales, Overview of Speech and Language Impairments. http://www.childspeech.net/u_i.html downloaded: $1^{\text {st }}$ October 2012.

3. Danny Steinberg, Psycholinguistics, New York: Longman Group, 1982, p. 45

4. Saville-Troike, M., Introducing Second Language Acquisition. Cambridge: Cambridge University Press, 2006, p. 34-35

5. Clark and Clark, Psychology and Language. An Introduction to Psycholinguistics. London: Harcourt Brace JAvanovich Publishers, 1977, p. 182

6. Ibid, p. 183

7. Sitti Nurpahmi, Buginese Phonemes, a Research Report, Nonpublished, 2008.

\section{BIBLIOGRAPHY}

Clark and Clark. Psychology and Language: An Introduction to Psycholinguistics. London: Harcourt Brace Javanovich Publishers, 1977.

Gitsaki, Christina. "Second Language Acquisition Theories: Overview and Evaluation." Article retrieved from http://www.secondlanguageacquisitiontheories.//webPages/Langteach//htm. $12^{\text {th }}$ June 2007

Morales, Sarah. "Overview of Speech and Language Impairments." http://www.childspeech.net/u_i.html downloaded: 1 ${ }^{\text {st }}$ October 2012.

Nurpahmi, Sitti. "Buginese Phonemes. a Research Report." Nonpublished, 2008.

Sapir, Edward. An Introduction to the Study of Speech. Project of Guttenburg, 2004.

Steinberg, Danny. Psycholinguistics. New York : Longman Group 2, 1982. 